\title{
Prediction of growth of Pseudomonas fluorescens in milk during storage under fluctuating temperature
}

\author{
Hao Lin, ${ }^{*}$ Mohammad Shavezipur, $†$ Ahmed Yousef, ${ }^{*}$ and Farnaz Maleky* \\ *Department of Food Science and Technology, and \\ †Department of Food, Agricultural and Biological Engineering, The Ohio State University, Columbus 43210
}

\begin{abstract}
Accurate prediction of growth of undesirable organisms (e.g., Pseudomonas fluorescens) in perishable foods (e.g., milk), held under sub-ideal storage conditions, can help ensure the quality and safety of these foods at the point of consumption. In this investigation, we inoculated sterile milk with $P$. fluorescens $\left(\sim 10^{3} \mathrm{cfu} /\right.$ $\mathrm{mL}$ ) and monitored inoculum growth behavior at constant and fluctuating storage temperatures. Three storage temperatures, $4^{\circ} \mathrm{C}, 15^{\circ} \mathrm{C}$ and $29^{\circ} \mathrm{C}$, were selected to simulate proper refrigeration conditions $\left(4^{\circ} \mathrm{C}\right)$ and temperature abuse, respectively. To simulate temperature fluctuation, milk held at $4^{\circ} \mathrm{C}$ was subjected to temperature shifts to $15^{\circ} \mathrm{C}$ or $29^{\circ} \mathrm{C}$ for 4 to $6 \mathrm{~h}$. A modified logistic model was used to obtain the best-fit curve for the microbial growth under constant storage temperature. The specific growth rates at $4^{\circ} \mathrm{C}, 15^{\circ} \mathrm{C}$, and $29^{\circ} \mathrm{C}$, obtained from experimental data, were 0.056 $\pm 0.00,0.17 \pm 0.05$, and $0.46 \pm 0.02 \mathrm{~h}^{-1}$, respectively, and the lag time values were $29.5 \pm 4.2,12.7 \pm 4.4$, and $2.8 \pm 0.3 \mathrm{~h}$, respectively. A model predicting bacterial growth under different temperature fluctuations was obtained using the growth parameters extracted from constant temperature experiments. Growth behavior predicted by the fluctuating temperature model and that obtained experimentally were in good agreement. Lag time exhibited a larger variation compared with specific growth rate, suggesting that it depends not only on growth temperature but also on the sample population and temperature gradient. Additionally, experimental data showed that changing the temperature during the lag phase induced an additional lag time before growth; however, no significant lag time was observed under the temperature fluctuation during the exponential phase. The results of this study provide information for precise shelf-life determination
\end{abstract}

Received July 28, 2015.

Accepted September 23, 2015.

${ }^{1}$ Corresponding author: maleky.1@osu.edu and reduction of food waste, particularly for milk and milk-containing food products.

Key words: Pseudomonas fluorescens, shelf life, spoilage, prediction of growth, temperature fluctuation

\section{INTRODUCTION}

One of the major challenges facing the food industry in the 21st century is supplying sufficient food for the growing population. The world population is expected to increase rapidly in the foreseeable future, reaching 8.1 billion in 2025 and 9.6 billion in 2050 (United Nations, 2014). Therefore, great efforts are required to increase food production to meet the demand for feeding the world population. However, increasing world food production may not be the only solution when a significant portion of produced food is discarded or lost uneaten. Food supply chain contributes the greatest waste among all major industries, and nearly $40 \%$ of food in the United States is wasted at different stages, including production, processing, packaging, distribution, retail, and in the consumer's home (Gunders, 2012). Surprisingly, retail and consumer waste account for a large proportion of the total waste. For instance, $50 \%$ of the total waste in grain product, seafood, and milk is incurred by consumers (Gustavsson et al., 2011).

Although there are numerous reasons for food waste, the main cause is food spoilage due to physical damage, chemical reaction, or microbial growth. Among all causes, microbial activity is the most important factor, accounting for a quarter of food loss (in't Veld, 1996). Given the conditions under which food is produced, processed, or stored, it should be possible to accurately predict microbial growth, and hence the final product's shelf life. Processor-defined shelf life may not reflect the actual time of spoilage because it is deliberately underestimated to account for potential abuse during storage and to ensure the quality and safety of the product (Skinner et al., 1994; Kilcast and Subramaniam, 2000). Hence one of the best approaches to reduce wasting food is to predict its actual shelf life.

To determine the actual shelf life of food, the environmental parameters and the response of food to those 
parameters should be known. One such important environmental factor is the storage temperature, which can vary during postharvest processes. It is nearly impossible to maintain a constant temperature at different stages of the food supply chain including transportation and consumers' homes. Therefore, food products may encounter a storage temperature that deviates from their standard and recommended value. This temperature variation during storage and handling could have a huge influence on microbial activity, which is a decisive factor for food spoilage. Hence, it is essential to take into account the time-temperature profile of microbial activities for monitoring food spoilage and establishing a realistic shelf life (Baranyi and Roberts, 1995; Semenov et al., 2007; Gospavic et al., 2008).

Microbial growth often appears sigmoidal, which can be described efficiently by Logistic and Gompertz models. Modifications have been applied to these models to improve their accuracy and suitability (Gibson et al., 1987; Zwietering et al., 1990). To take into consideration the temperature variation during the storage and to better predict shelf life, dynamic models provide ways to describe the influence of variable temperature on microbial growth (Van Impe et al., 1992; Baranyi et al., 1995; Bovill et al., 2000). A 2-step approach is generally used to construct a dynamic model for growth prediction. First, the experimental data are generated under constant temperature and a mathematical model (known as the primary model) is developed to describe the relationship between microbial population in food and storage time. The second step is to evaluate the dependence of parameters used in the model on temperature, and such a function or relationship is considered the secondary model (McKellar and Lu, 2003; Gospavic et al., 2008; Peleg and Corradini, 2011).

The objective of this work was to investigate the feasibility of predicting microbial growth in contaminated food based on storage temperature, particularly when it is fluctuating. Pseudomonas fluorescens, a ubiquitous psychrotrophic spoilage bacterium, was tested in this investigation. The bacterium is known to cause spoilage in several foods by producing extracellular enzymes such as lipases and proteases when the bacterial population reaches or exceeds $\sim 10^{6} \mathrm{cfu} / \mathrm{g}$ ( or $\mathrm{cfu} / \mathrm{mL}$ ) in a food product (Ternström et al., 1993). If milk is contaminated before processing, the extracellular enzymes would remain active after HTST treatment (Chen et al., 2003), causing a reduction in shelf life. Similar risks are expected when pasteurized milk is exposed to the bacterium as a postprocessing contaminant. Therefore, growth of $P$. fluorescens in pasteurized milk exposed to temperature abuse was monitored experimentally and modeled mathematically in this study; the results should provide fundamental knowledge for applying the concept to other foods and spoilage microorganisms.

\section{MATERIALS AND METHODS}

\section{Culture Preparation and Milk Inoculation}

Fresh culture of $P$. fluorescens was inoculated into tryptic soy broth (Difco/Becton, Dickinson and Company, Franklin Lakes, NJ) and incubated at $29^{\circ} \mathrm{C}$ for 24 h. Incubated culture $\left(\sim 10^{9} \mathrm{cfu} / \mathrm{mL}\right.$ P. fluorescens $)$ was diluted in $0.1 \%$ peptone water (Difco/Becton, Dickinson and Company) and inoculated into UHT-pasteurized low-fat (1\%) milk (Horizon Organic, Broomfield, $\mathrm{CO})$ at the rate of approximately $10^{3}$ to $10^{4} \mathrm{cfu} / \mathrm{mL}$. Aliquots $(0.5 \mathrm{~mL})$ of inoculated milk were dispensed into micro-centrifuge tubes and held at controlled temperature in an incubator (Benchmark Scientific Inc., Edison, NJ). Samples were taken at appropriate time intervals (every $1 \mathrm{~h}$ at $29^{\circ} \mathrm{C}$, every $3 \mathrm{~h}$ at $15^{\circ} \mathrm{C}$, and every $12 \mathrm{~h}$ at $4^{\circ} \mathrm{C}$ ) and the population of $P$. fluorescens was enumerated as described later.

\section{Temperature Variation}

Inoculated milk samples were held under 2 different experimental conditions: constant $\left(4^{\circ} \mathrm{C}, 15^{\circ} \mathrm{C}\right.$, and $29^{\circ} \mathrm{C}$ ) and fluctuating temperatures. To mimic ambient temperature in summer, $29^{\circ} \mathrm{C}$ was selected based on the average high temperature during summer in Columbus, Ohio. For variable temperature experiments, 3 patterns of temperature fluctuation were used, as presented in Figure 1 and Table 1. In the first and second patterns, the single temperature fluctuation happened at 24 or $48 \mathrm{~h}$ of storage and lasted $6 \mathrm{~h}$ at $15^{\circ} \mathrm{C}$ and $4 \mathrm{~h}$ at $29^{\circ} \mathrm{C}$. In the second pattern, the first temperature fluctuation happened at $24 \mathrm{~h}$ and the second occurred $24 \mathrm{~h}$ after the first was completed. For this set of experiments, the time interval between data points was $12 \mathrm{~h}$ at $4^{\circ} \mathrm{C}, 90$ min at $15^{\circ} \mathrm{C}$, and $60 \mathrm{~min}$ at $29^{\circ} \mathrm{C}$.

\section{Determination of Population and Growth Curve}

One micro-centrifuge tube was taken as a sample at each data point. The sample was then diluted 10-fold in $0.1 \%$ peptone water, and $0.1 \mathrm{~mL}$ of appropriate dilution was spread onto a tryptic soy agar plate. Inoculated plates were incubated aerobically at $29^{\circ} \mathrm{C}$ for $48 \mathrm{~h}$, colonies were counted, and population was calculated (cfu/mL).

Mathematical software (Matlab, version: r2014a; The Mathworks Inc., Natick, MA) was used to analyze growth data. Using nonlinear regression, microbial 

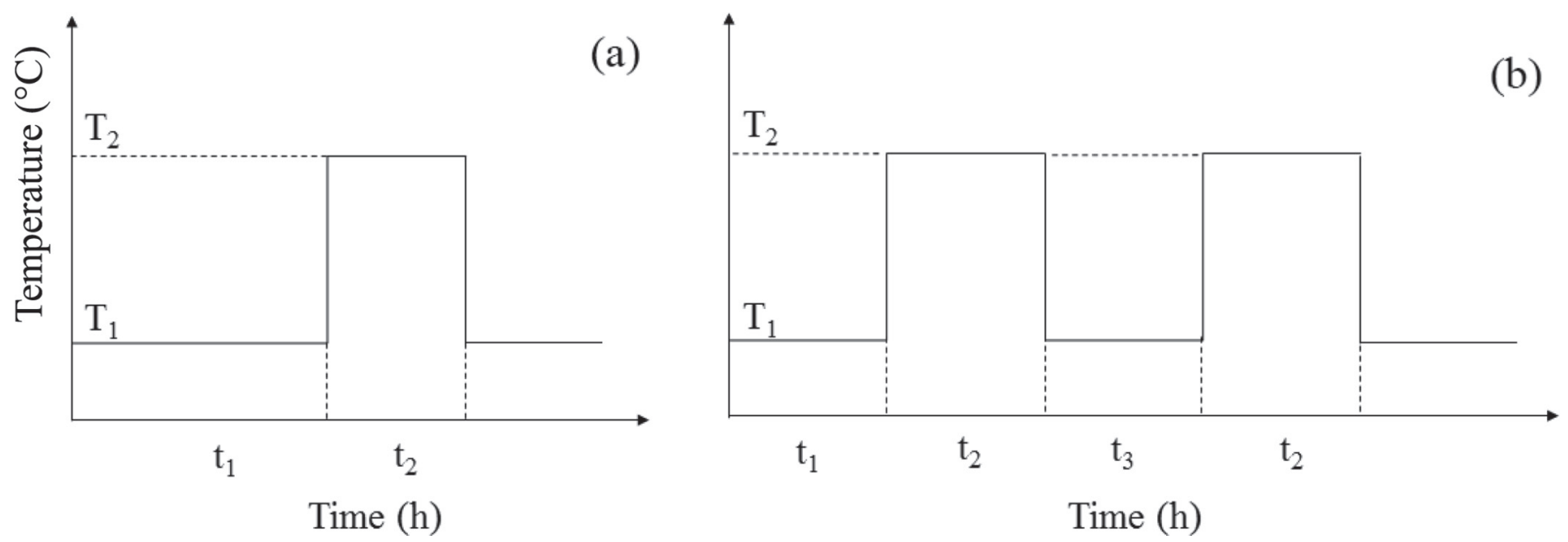

Figure 1. Patterns of temperature (T) fluctuation over storage time (t) with (a) 1 fluctuation, and (b) 2 fluctuations.

count data were fitted to the modified logistic function shown in Eq. [1] (Zwietering et al., 1990) to obtain population $N(t)$ as a function of initial population $\left(\boldsymbol{N}_{\mathbf{0}}\right)$, specific growth rate $(\boldsymbol{\mu})$ and lag time $(\boldsymbol{\lambda})$ :

$$
\log _{10} N(t)=\log _{10} N_{0}+\frac{A}{\left\{1+\exp \left[\frac{4 \mu}{A}(\lambda-t)+2\right]\right\}},[1]
$$

where $t$ is the storage time in hours, and $A$ is the $\log$ ratio of maximum and initial populations:

$$
A=\log _{10}\left(\frac{N_{\max }}{N_{0}}\right) \text {. }
$$

The maximum generation time (MGT) was obtained from (Yousef et al., 1991; Delignette-Muller, 1998)

$$
\mathrm{MGT}=\left(\frac{\log _{10}(2)}{\mu}\right)
$$

The dependence of specific growth rate, lag time, and time to maximum population on temperature were analyzed as described later.

\section{RESULTS AND DISCUSSION}

\section{Growth Curves at Constant Temperature}

Incubation of $P$. fluorescens in milk at constant temperatures produced typical growth curves (Figure 2) compared with published data (Gospavic et al., 2008; Chen et al., 2011). To describe the microbial growth as a function of storage time, a modified logistic model (Eq. [1]) was used and growth parameters were directly obtained from nonlinear regression analysis (Table 2). The maximum growth rates for storage at $4^{\circ} \mathrm{C}, 15^{\circ} \mathrm{C}$, and $29^{\circ} \mathrm{C}$ were $0.056,0.17$, and $0.46 \mathrm{~h}^{-1}$, respectively, and the MGT were $6.42,2.82$, and $0.81 \mathrm{~h}$, respectively, which are in agreement with published data for milk (Cox and MacRae, 1988).

To examine the fitness of model to experimental data, a fitted curve for $4^{\circ} \mathrm{C}$ with $99 \%$ confidence limits is presented (Figure 3). As shown in this figure, almost all measured data points were located inside the upper and lower confidence bounds, indicating that the modified logistic model provided a good fit for the growth of P. fluorescens at $4^{\circ} \mathrm{C}$ in low-fat milk. As expected, when incubation temperature increased from $4^{\circ} \mathrm{C}$ to $29^{\circ} \mathrm{C}$, the lag time decreased from 29.5 to $2.8 \mathrm{~h}$ and

\begin{tabular}{|c|c|c|c|c|c|}
\hline \multirow[b]{2}{*}{ Test } & \multicolumn{2}{|c|}{ Temperature $\left({ }^{\circ} \mathrm{C}\right)$} & \multicolumn{3}{|c|}{ Time (h) } \\
\hline & $T_{1}$ & $T_{2}$ & $t_{1}$ & $t_{2}$ & $t_{3}$ \\
\hline One fluctuation (Figure 1a) & 4 & 15 or 29 & 24 & $4 \mathrm{~h}$ at $29^{\circ} \mathrm{C}, 6 \mathrm{~h}$ at $15^{\circ} \mathrm{C}$ & $\mathrm{NA}^{1}$ \\
\hline One fluctuation (Figure 1a) & 4 & 15 or 29 & 48 & $4 \mathrm{~h}$ at $29^{\circ} \mathrm{C}, 6 \mathrm{~h}$ at $15^{\circ} \mathrm{C}$ & NA \\
\hline Two fluctuations (Figure 1b) & 4 & 15 or 29 & 24 & $4 \mathrm{~h}$ at $29^{\circ} \mathrm{C}, 6 \mathrm{~h}$ at $15^{\circ} \mathrm{C}$ & 24 \\
\hline
\end{tabular}
specific growth rate increased from 0.06 to $0.46 \mathrm{~h}^{-1}$. It

Table 1. Temperature $(T)$ values and time $(t)$ intervals in fluctuation tests illustrated in Figure 1

${ }^{1}$ Not applicable. 

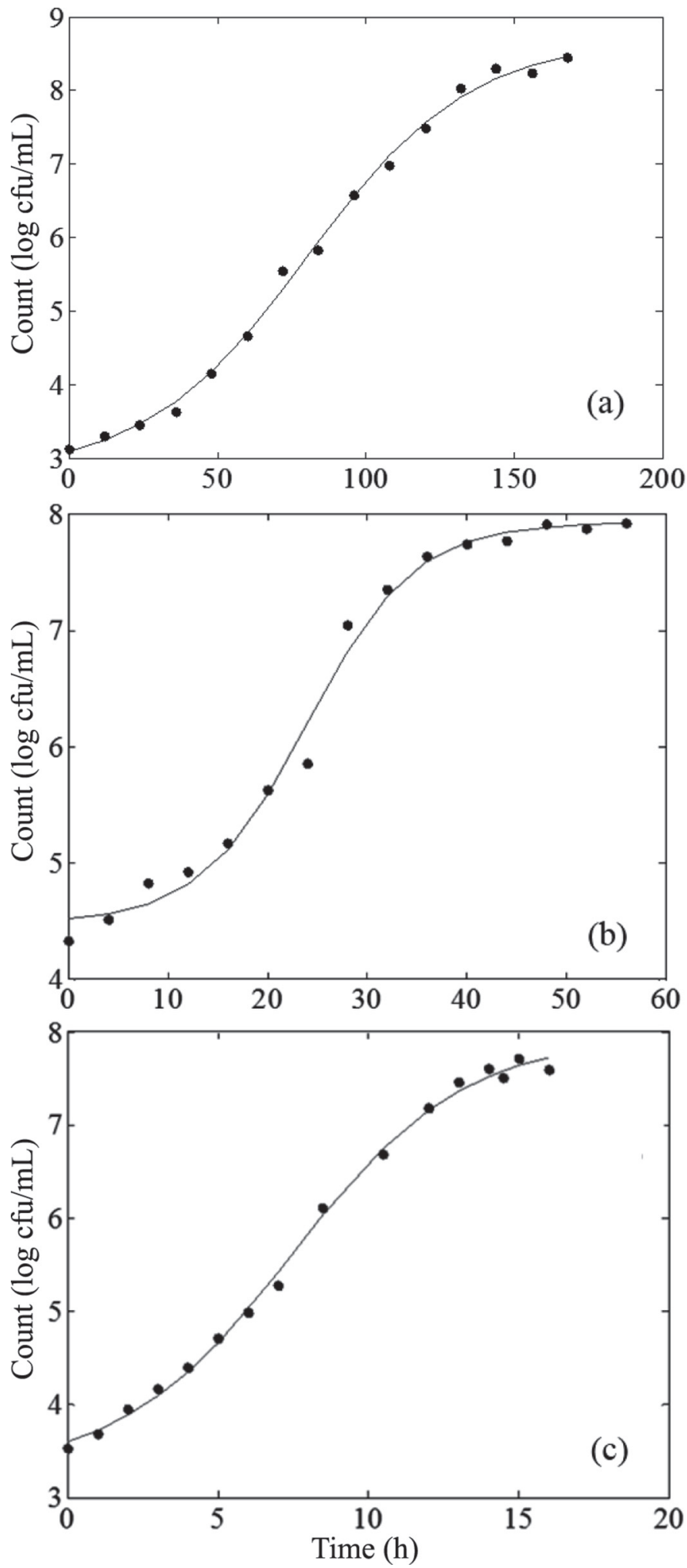

Figure 2. Experimental data for growth of Pseudomonas fluorescens in milk (-) and fitted modified logistic model (solid line) for samples stored at (a) $4^{\circ} \mathrm{C}$, (b) $15^{\circ} \mathrm{C}$, and (c) $29^{\circ} \mathrm{C}$ (results averaged from 4 replicates at $4^{\circ} \mathrm{C}$ or 3 replicates at $15^{\circ} \mathrm{C}$ and $29^{\circ} \mathrm{C}$ ). is notable that lag time exhibited a larger variation for each temperature compared with specific growth rate (Table 2). This is believed to be due to the dependence of lag time on the cells' previous history in addition to new environmental conditions (Baranyi et al., 1995; Bovill et al., 2000). Baranyi et al. (1995) suggested that the cells' history could be very different even for the same inoculum population, depending on metabolic activity in the preinoculation environment. Consequently, the physiological state of cells before inoculation might result in a large variation in lag time.

The temperature dependence of specific growth rate is shown in Figure 4a. A linear relationship between square root of specific growth rate, $\mu$, and temperature, $T$, known as the Ratkowsky square root model is presented as follows (Ratkowsky et al., 1982, 1983; Zwietering et al., 1991):

$$
\sqrt{\mu}=c\left(T-T_{0}\right)
$$

where $c$ is the slope of regression line and $T_{0}$ is a conceptual temperature where the extrapolation of the regression line intersects the $T$ axis, and is considered as a hypothetical minimum growth temperature. The conceptual temperature $T_{0}$ is an intrinsic property of the microorganism (Ratkowsky et al., 1982), and its value for the data obtained in this work was $264 \mathrm{~K}\left(-9.15^{\circ} \mathrm{C}\right)$. This is in a good agreement with published data for Pseudomonas group when $T_{0}$ is reported at the range of $263 \mathrm{~K}$ to $272 \mathrm{~K}\left(-10.15^{\circ} \mathrm{C}\right.$ to $-1.15^{\circ} \mathrm{C}$; Ratkowsky et al., 1982; Phillips and Griffiths, 1987).

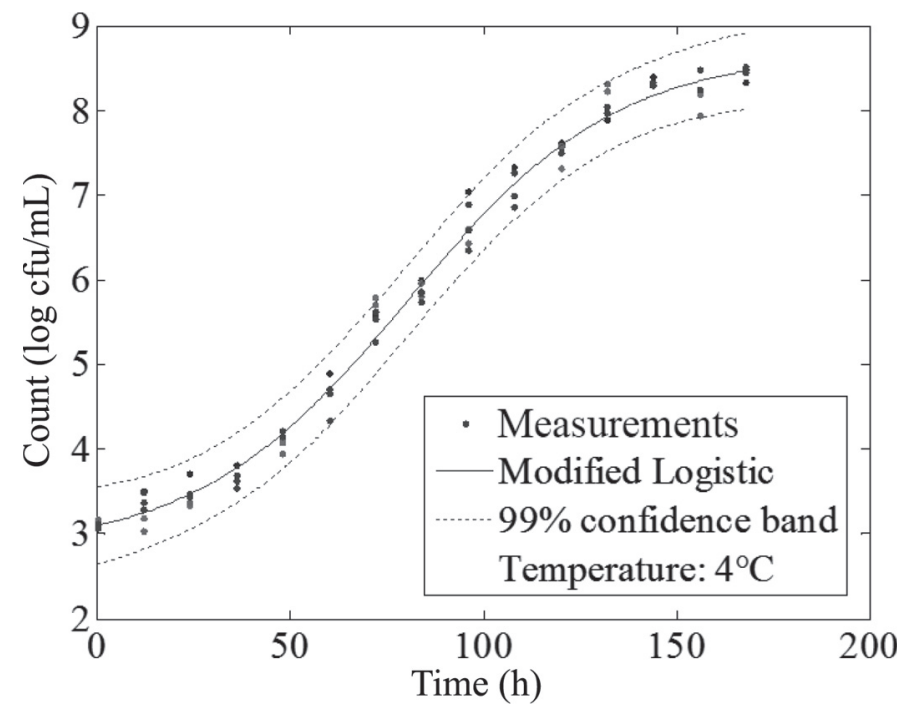

Figure 3. Growth curve fitted by modified logistic model for $4^{\circ} \mathrm{C}$ with $99 \%$ confidence band and 5 sets of measured data points. 
Table 2. Initial population, asymptote, maximum specific growth rate $(\mu)$, lag time $(\lambda)$, and maximum generation time (MGT) determined using experimental data and the modified logistic model (means $\pm \mathrm{SD}$ )

\begin{tabular}{|c|c|c|c|c|c|}
\hline $\begin{array}{l}\text { Temperature } \\
\left({ }^{\circ} \mathrm{C}\right)\end{array}$ & $\begin{array}{l}\text { Initial population } \\
\quad(\log \mathrm{cfu} / \mathrm{mL})\end{array}$ & $\begin{array}{l}\text { Asymptote } \\
(\log \mathrm{cfu} / \mathrm{mL})\end{array}$ & $\mu(1 / \mathrm{h})$ & $\lambda(\mathrm{h})$ & MGT (h) \\
\hline 4 & $2.9 \pm 0.2$ & $5.667 \pm 0.2$ & $0.056 \pm 0.00$ & $29.5 \pm 4.2$ & $6.42 \pm 0.65$ \\
\hline
\end{tabular}

The relation between the reciprocal of specific growth rate and the lag time (Figure $4 \mathrm{~b}$ ) was found to be linear:

$$
\lambda=b(1 / \mu)+a
$$

where $\lambda$ is the lag time, $1 / \mu$ is the reciprocal of specific growth rate, and $b$ and $a$ are regression parameters. The regression analysis showed a strong linear relationship between the 2 parameters $\left(\mathrm{R}^{2}=0.9834\right)$. This relation explains how the lag time represents the work necessary for cells to adjust to a new environment ( $\mathrm{Li}$ and Torres, 1993; Koutsoumanis, 2001; Brown, 2007).

\section{Modeling Growth Under Temperature Fluctuations}

Two patterns of temperature change, single and double fluctuations, were used to simulate temperature abuse, and the storage temperature was increased above refrigeration temperature $\left(4^{\circ} \mathrm{C}\right)$ in each fluctuation. Single fluctuations occurred during the lag and exponential phases (Figure 1 and Table 1). To predict bacterial growth under temperature fluctuation, the time of entire growth curve was divided into intervals of constant temperature, and the following modified logistic model was used:

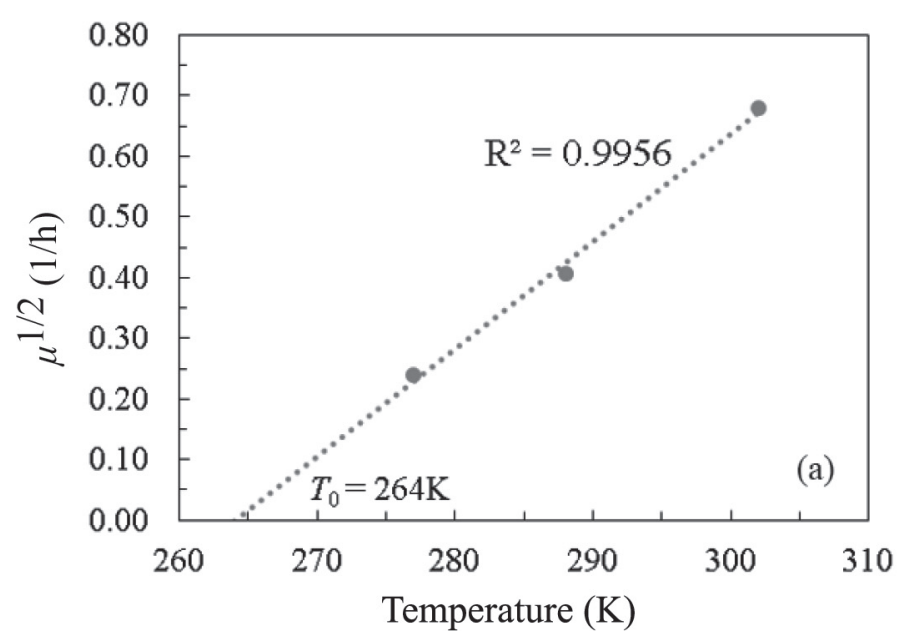

$\log N(t)=\log N_{i}$

$$
+\frac{\log \left(N_{\max } / \log N_{i}\right)}{\left\{1+\exp \left[\frac{4 \mu_{i}}{\left(\log N_{\max }-\log N_{i}\right)}\left(\lambda_{i}-t+t_{i}\right)+2\right]\right\}},
$$

where $t$ is the storage time in hours, $N_{i}$ is the microbial population at the beginning of temperature change $t_{i}$, and $N_{\max }$ is the maximum population. The temperature is constant for $t_{i}<t<t_{i+1}$, and $\lambda_{i}$ and $\mu_{i}$ are the lag time and specific growth rate for this time interval, respectively (Zwietering et al., 1990).

The value of specific growth rate $\mu_{i}$ corresponding to $T_{i}$ of each fluctuation interval is calculated using Eq. [4], and the lag time, $\lambda_{i}$, is approximated using Eq. [5]; however, variation of lag time should be taken into consideration. It was reported that the lag time under variable temperature conditions deviates from that obtained under constant temperature (Ng et al., 1962; Zwietering et al., 1994; Bernaerts et al., 2002).

Bacterial growth with one fluctuation and the corresponding mathematical models are shown in Figure 5 . The storage temperature $\left(4^{\circ} \mathrm{C}\right)$ was increased $\left(29^{\circ} \mathrm{C}\right.$

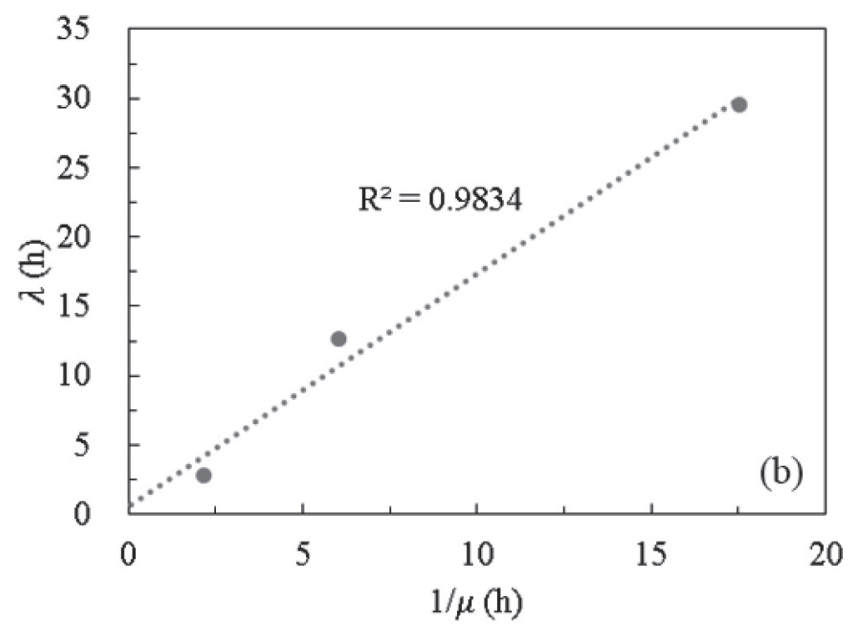

Figure 4. (a) Temperature dependence of the specific growth rate $\left(\mu^{1 / 2}\right)$ obtained by modified logistic model; (b) correlation of lag time $(\lambda)$ and specific growth rate $(\mu) . T_{0}$ is a conceptual temperature where the extrapolation of the regression line intersects the $T$ axis. 

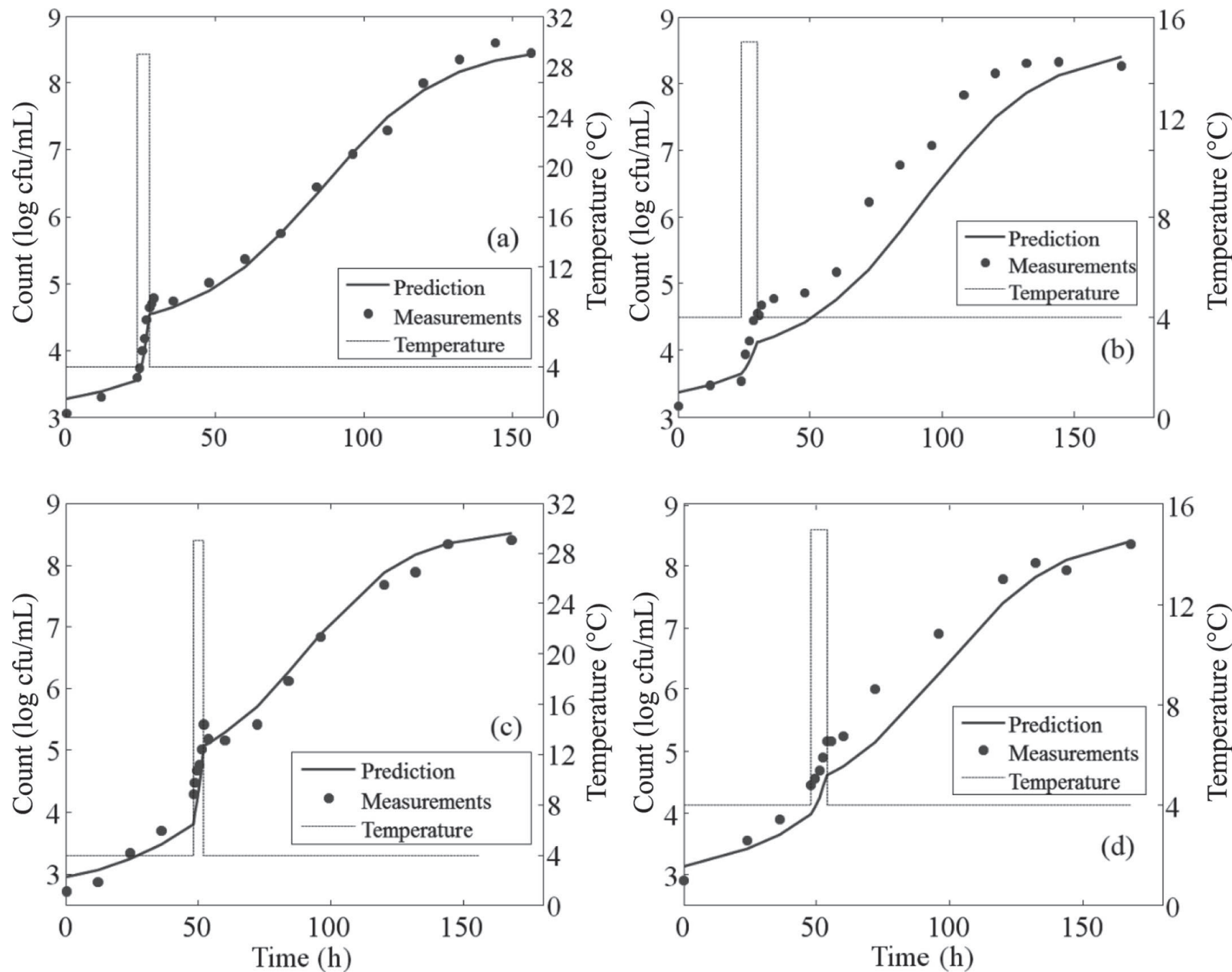

Figure 5. Prediction (solid line) and experimental data $(\bullet)$ of Pseudomonas fluorescens in milk with 1 temperature fluctuation (a) at $24 \mathrm{~h}$ (temperature increased to $29^{\circ} \mathrm{C}$ for $4 \mathrm{~h}$ ); (b) at $24 \mathrm{~h}$ (temperature increased to $15^{\circ} \mathrm{C}$ for $6 \mathrm{~h}$ ); (c) at $48 \mathrm{~h}$ (temperature increased to $29^{\circ} \mathrm{C}$ for 4 h); and (d) at $48 \mathrm{~h}$ (temperature increased to $15^{\circ} \mathrm{C}$ for $6 \mathrm{~h}$ ). Results were averaged from 2 replicates in both trials.

in Figure 5a, and $15^{\circ} \mathrm{C}$ in Figure 5b) after 24-h holding; this fluctuation coincided with the lag phase. In response to the temperature increase, the bacterium expressed short or no obvious additional lag time. Zwietering et al. (1994) suggested that in such a case, the length of an additional lag is one-fourth the lag time that normally happens for that temperature. When the temperature decreased to $4^{\circ} \mathrm{C}$, a longer lag time was observed. The lag after temperature decrease is similar to the lag observed at the beginning of the growth curve. To further analyze the duration of lag, the changes in population after temperature fluctuation were fitted to a modified logistic model (Eq. [1]) as a new independent growth. The results showed that the new lag times were $17.4 \mathrm{~h}$ (Figure 5a) and $15.0 \mathrm{~h}$ (Figure 5b), which is close to half of the lag at constant $4^{\circ} \mathrm{C}(\lambda=29.5 \mathrm{~h})$. In this scenario, an acceptable agreement between prediction and experimental data was obtained by incorporating half a standard lag time in Eq. [5].

When a fluctuation was introduced during the exponential phase - that is, after $48 \mathrm{~h}$ of storage at $4^{\circ} \mathrm{C}-\mathrm{a}$ different pattern of lag phase during and after temperature fluctuation was observed (Figures $5 \mathrm{c}$ and $5 \mathrm{~d}$ ). Some studies suggest that temperature change during the exponential phase causes no lag time (Zwietering et al., 1994; Kreyenschmidt et al., 2010). Therefore, the specific growth rate changes instantaneously as temperature changes and the additional lag phase is neglected in the model. The prediction afforded by the model provided a good agreement with experimental 

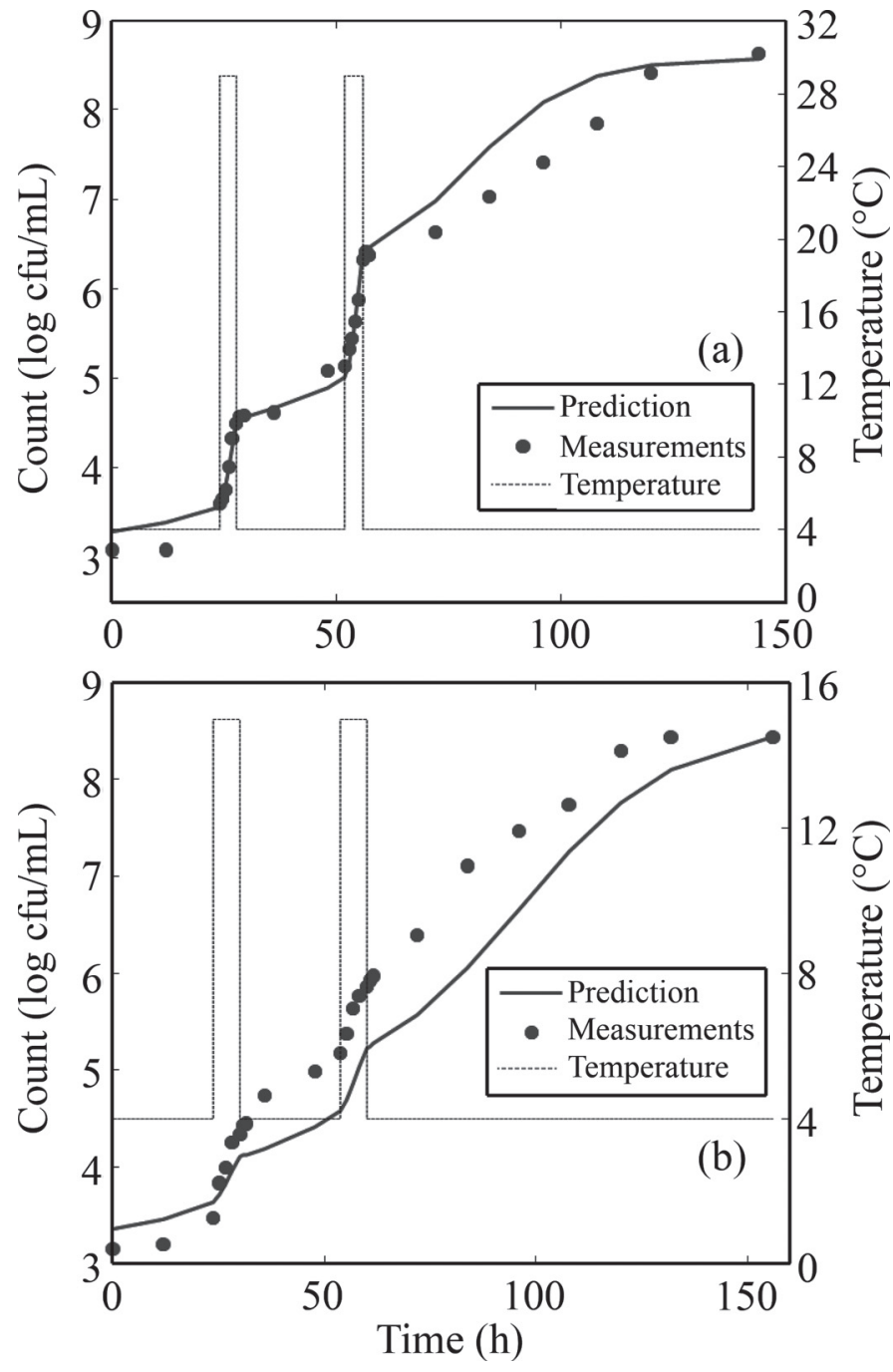

Figure 6. Prediction (solid line) and experimental data (-) of Pseudomonas fluorescens in milk with 2 temperature fluctuations with (a) temperature increasing to $29^{\circ} \mathrm{C}$ for $4 \mathrm{~h}$ in each fluctuation; and (b) temperature increasing to $15^{\circ} \mathrm{C}$ for $6 \mathrm{~h}$ in each fluctuation. Results were averaged from 2 replicates in both trials.

data, whereas the use of proportional lag may result in underestimated growth.

The prediction of the growth with 2 fluctuations, one in the lag phase and the other in the exponential phase, is displayed in Figure 6. These data were modeled using a combination of assumptions used in Figure 5. Even though prediction after the second temperature fluctuation was overestimated, the model showed good agreement with experimental growth data (Figure 6a). However, the prediction underestimated the growth when temperature was shifted from $4^{\circ} \mathrm{C}$ to $15^{\circ} \mathrm{C}$ (Figure $6 \mathrm{~b})$. Because no lag time was considered for this region, the fitted data predicted the maximum possible growth based on data obtained from constant temperature.
The modified logistic model (Eq. [1] and [6]) generally provided an acceptable prediction for growth of $P$. fluorescens in milk. The value of lag incorporated into the model played an important role in the accuracy of the prediction. Predictions received a better degree of agreement among the experiments in which temperature changed from $4^{\circ} \mathrm{C}$ to $29^{\circ} \mathrm{C}$, which indicates that the temperature gradient during fluctuation may be a factor affecting the lag. The effects of temperature change on lag have been discussed previously. It is thought that a large and abrupt temperature shift may result in a new adaptation phase ( $\mathrm{Ng}$ et al., 1962; Bernaerts et al., 2002). Baranyi et al. (1995) and Zwietering et al. (1994) also found that temperature shifts around the minimum growth temperature showed large deviations from the model predictions. Moreover, lag time could be affected by the size of the microbial population, which can be seen from the new and independent growth after fluctuation in Figure 5. Therefore, for further refinement of bacterial growth prediction, additional studies are needed to incorporate the effect of growth history, population, and temperature gradient on lag time.

\section{Effect of Temperature Fluctuation on Shelf Life of Processed Milk}

In this study, pasteurized milk with postprocessing contamination was simulated by inoculating commercially sterile milk with a small population of $P$. fluorescens. When this psychrotrophic bacterium is found in milk as a postpasteurization contaminant, it becomes the main reason for termination of product shelf-life. Other psychrotrophic bacteria that survive milk pasteurization also cause spoilage of pasteurized milk (Blackburn, 2006; Momani and Natsheh, 2012). The shift from refrigeration $\left(4^{\circ} \mathrm{C}\right)$ to higher temperatures $\left(15^{\circ} \mathrm{C}\right.$ and $\left.29^{\circ} \mathrm{C}\right)$ simulated temperature abuse during storage. This study aimed to illustrate how to predict the detrimental effect of the combination of temperature abuse and presence of psychrotrophic population on product quality and shelf life. It is estimated that a population of $10^{6} \mathrm{cfu}$ of milk contaminant $/ \mathrm{mL}$ of milk is sufficient to cause product spoilage (Momani and Natsheh, 2012).

Temperature increase after $48 \mathrm{~h}$ of refrigerated storage to $29^{\circ} \mathrm{C}$ resulted in an approximately 1-log increase in population of $P$. fluorescens (Figure 7a). It took almost $1.5 \mathrm{~d}$ for the control group (stored at refrigeration temperature, $4^{\circ} \mathrm{C}$ ) to reach the same population that the test group had at the end of the fluctuation, meaning that this fluctuation could reduce the shelflife by $1 \mathrm{~d}$, at least. Similarly, the population increase during temperature fluctuation at $24 \mathrm{~h}$ of storage was 

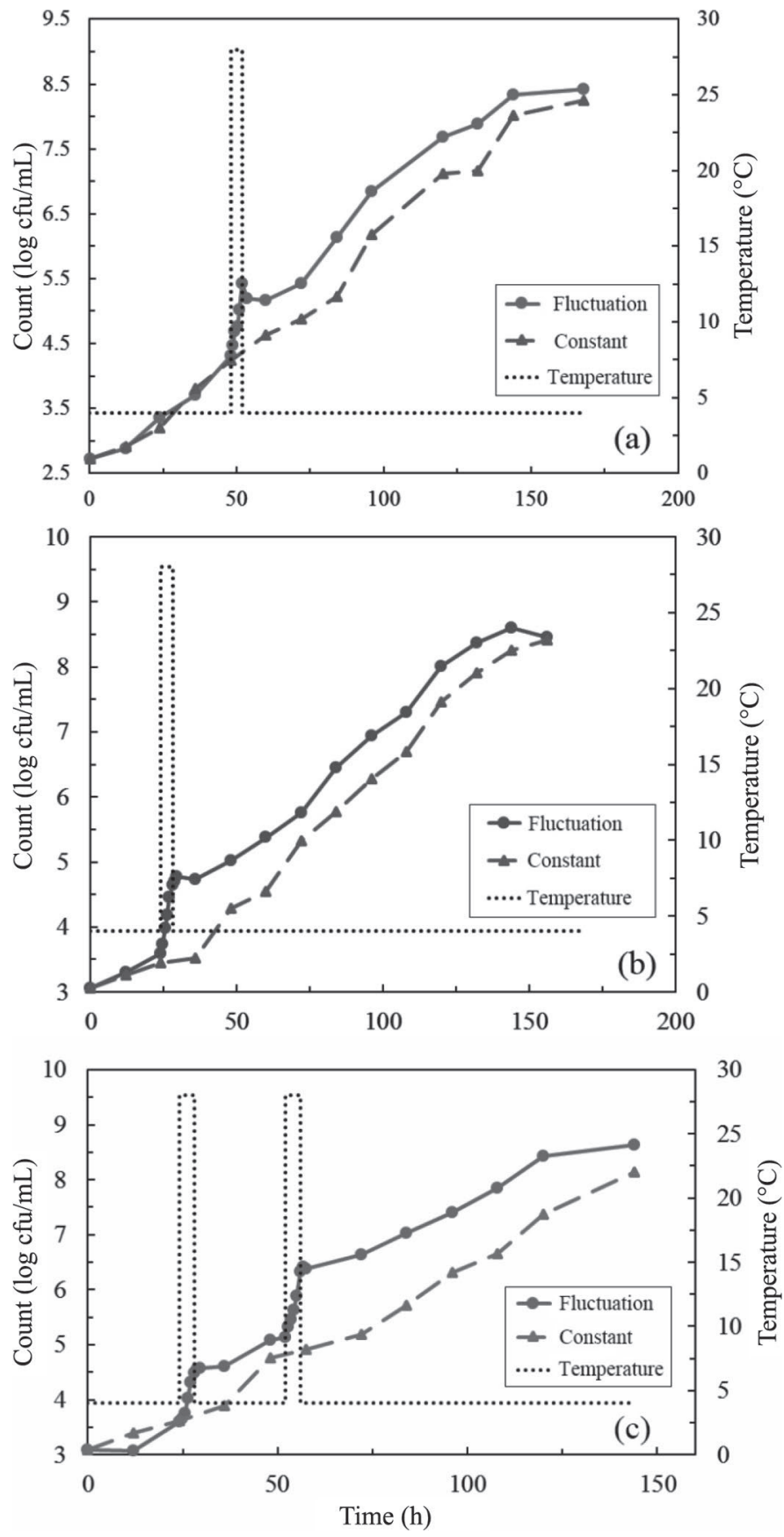

Figure 7. Growth of Pseudomonas fluorescens in milk when the temperature increases from $4^{\circ} \mathrm{C}$ to $29^{\circ} \mathrm{C}$ for $4 \mathrm{~h}$ : (a) and (b) show 1 fluctuation after 48 and $24 \mathrm{~h}$, respectively, and (c) 2 fluctuations. Results were averaged from 2 replicates in all trials.

approximately $1 \log (\mathrm{cfu} / \mathrm{mL}$ ) (Figure $7 \mathrm{~b})$; however, for the control group stored at $4^{\circ} \mathrm{C}$, it took longer (almost $2 \mathrm{~d}$ ) to reach the same population that the test group reached at the end of fluctuation. These results suggest that if the temperature abuse happens early in storage, the time to reach the maximum population of bacteria is drastically decreased, leading to shorter shelf life. If the temperature fluctuation occurs later, the time to reach the maximum population is less affected; nonetheless, the bacterial population may reach the spoilage threshold $\left(\sim 10^{6} \mathrm{cfu} / \mathrm{mL}\right)$ during the fluctuation.

When temperature fluctuations were introduced at $24 \mathrm{~h}$ of refrigerated storage and again $24 \mathrm{~h}$ after the first one ended, an increase in the population of $P$. fluorescens of approximately $1 \log (\mathrm{cfu} / \mathrm{mL})$ was observed during each fluctuation (Figure 7c). When milk was stored at constant temperature, it took about 90 $\mathrm{h}$ for $P$. fluorescens to reach a population of $10^{6} \mathrm{cfu} /$ $\mathrm{mL}$, which could be considered as the start of spoilage in milk. However, after 2 temperature fluctuations to $29^{\circ} \mathrm{C}$, P. fluorescens took only $55 \mathrm{~h}$ to reach that population size, highlighting the effect of temperature abuse on shelf-life, which could be cut by $40 \%$ if the milk is exposed to higher temperature in a short period.

The experimental data presented in this work emphasize the importance of the temperature abuse and its effect on the actual shelf life of a food product. Our data also suggest that if the storage temperature is continuously monitored after production by using the mathematical model presented in Eq. [6], an actual and accurate shelf life of milk could be determined in real time.

In conclusion, we developed a model that can predict the shelf life of pasteurized milk, presumed to contain a small initial population of spoilage microorganisms, based on the temperature profile during storage. The results show that temperature abuse in the early stage of food storage could drastically reduce a product's shelf life.

\section{ACKNOWLEDGMENTS}

The authors acknowledge financial resources including the USDA National Institute for Food and Agriculture (Washington, DC) Hatch projects OHO01312, and Ohio Agricultural Research and Development Corporation (OARDC).

\section{REFERENCES}

Baranyi, J., and T. A. Roberts. 1995. Mathematics of predictive food microbiology. Int. J. Food Microbiol. 26:199-218.

Baranyi, J., T. P. Robinson, A. Kaloti, and B. M. Mackey. 1995. Predicting growth of Brochothrix thermosphacta at changing temperature. Int. J. Food Microbiol. 27:61-75.

Bernaerts, K., R. D. Servaes, S. Kooyman, K. J. Versyck, and J. F. Van Impe. 2002. Optimal temperature input design for estimation of the square root model parameters: Parameter accuracy and model validity restrictions. Int. J. Food Microbiol. 73:145-157.

Blackburn, C., ed. 2006. Food Spoilage Microorganisms. Woodhead Publishing, Cambridge, UK.

Bovill, R., J. Bew, N. Cook, M. D'agostino, N. Wilkinson, and J. Baranyi. 2000. Predictions of growth for Listeria monocytogenes and 
Salmonella during fluctuating temperature. Int. J. Food Microbiol. 59:157-165.

Brown, S. 2007. Two implications of common models of microbial growth. ANZIAM J. 49:C230-C242.

Chen, L. D. R. M., R. M. Daniel, and T. Coolbear. 2003. Detection and impact of protease and lipase activities in milk and milk powders. Int. Dairy J. 13:255-275.

Chen, T. R., Q. K. Wei, and Y. J. Chen. 2011. Pseudomonas spp. and Hafnia alvei growth in UHT milk at cold storage. Food Contr. 22:697-701.

Cox, J. M., and I. C. MacRae. 1988. Growth of psychrotrophic bacteria in raw and UHT-treated goats milk. J. Appl. Bacteriol. 64:403-407.

Delignette-Muller, M. L. 1998. Relation between the generation time and the lag time of bacterial growth kinetics. Int. J. Food Microbiol. 43:97-104

Gibson, A. M., N. Bratchell, and T. A. Roberts. 1987. The effect of sodium chloride and temperature on the rate and extent of growth of Clostridium botulinum type A in pasteurized pork slurry. J. Appl. Bacteriol. 62:479-490.

Gospavic, R., J. Kreyenschmidt, S. Bruckner, V. Popov, and N. Haque. 2008. Mathematical modelling for predicting the growth of Pseudomonas spp. in poultry under variable temperature conditions. Int. J. Food Microbiol. 127:290-297.

Gunders D. 2012. Wasted: How America is losing up to 40 percent of its food from farm to fork to landfill. Issue Paper. August. Natural Resources Defense Council, New York, NY.

Gustavsson, J., C. Cederberg, U. Sonesson, R. Van Otterdijk, and A. Meybeck. 2011. Global Food Losses and Food Waste. Food and Agriculture Organization of the United Nations, Rome, Italy

in't Veld, J. H. H. 1996. Microbial and biochemical spoilage of foods: An overview. Int. J. Food Microbiol. 33:1-18.

Kilcast, D., and P. Subramaniam. 2000. The stability and shelf-life of food. Woodhead Publ., Cambridge, UK.

Koutsoumanis, K. 2001. Predictive modeling of the shelf-life of fish under nonisothermal conditions. Appl. Environ. Microbiol. 67:18211829

Kreyenschmidt, J., A. Hübner, E. Beierle, L. Chonsch, A. Scherer, and B. Petersen. 2010. Determination of the shelf-life of sliced cooked ham based on the growth of lactic acid bacteria in different steps of the chain. J. Appl. Microbiol. 108:510-520.

Li, K. Y., and J. A. Torres. 1993. Microbial growth estimation in liquid media exposed to temperature fluctuations. J. Food Sci. 58:644-648.

McKellar, R. C., and X. Lu. 2003. Modeling Microbial Responses in Food. CRC Press, Boca Raton, FL

Momani, J., and A. Natsheh, ed. 2012. Raw Milk: Production, Consumption, and Health Effects. Nova Science Publishers, Hauppauge, NY.
Ng, H., J. L. Ingraham, and A. G. Marr. 1962. Damage and derepression in Escherichia coli resulting from growth at low temperatures. J. Bacteriol. 84:331-339.

Peleg, M., and M. G. Corradini. 2011. Microbial growth curves: What the models tell us and what they cannot. Crit. Rev. Food Sci. Nutr. 51:917-945.

Phillips, J. D., and M. W. Griffiths. 1987. The relation between temperature and growth of bacteria in dairy products. Food Microbiol $4: 173-185$

Ratkowsky, D. A., R. K. Lowry, T. A. McMeekin, A. N. Stokes, and R. E. Chandler. 1983. Model for bacterial culture growth rate throughout the entire biokinetic temperature range. J. Bacteriol. 154:1222-1226

Ratkowsky, D. A., J. Olley, T. A. McMeekin, and A. Ball. 1982. Relationship between temperature and growth rate of bacterial cultures. J. Bacteriol. 149:1-5.

Semenov, A. V., A. H. Van Bruggen, L. Van Overbeek, A. J. Termorshuizen, and A. M. Semenov. 2007. Influence of temperature fluctuations on Escherichia coli O157: H7 and Salmonella enterica serovar Typhimurium in cow manure. FEMS Microbiol. Ecol. 60:419-428.

Skinner, G. E., J. W. Larkin, and E. J. Rhodehamel. 1994. Mathematical modeling of microbial growth: A review. J. Food Saf. 14:175-217.

Ternström, A., A. M. Lindberg, and G. Molin. 1993. Classification of the spoilage flora of raw and pasteurized bovine milk, with special reference to Pseudomonas and Bacillus. J. Appl. Bacteriol. $75: 25-34$.

United Nations. 2014. World Population Prospects: The 2012 Revision. Methodology of the United Nations Population Estimates and Projections. ESA/P/WP.235. UN Department of Economic and Social Affairs, Population Division, United Nations, New York, NY

Van Impe, J. F., B. M. Nicolaï, T. Martens, J. De Baerdemaeker, and J. Vandewalle. 1992. Dynamic mathematical model to predict microbial growth and inactivation during food processing. Appl. Environ. Microbiol. 58:2901-2909.

Yousef, A. E., R. J. Gajewski II, and E. H. Marth. 1991. Kinetics of growth and inhibition of Listeria monocytogenes in the presence of antioxidant food additives. J. Food Sci. 56:10-13.

Zwietering, M. H., J. T. De Koos, B. E. Hasenack, J. C. De Witt, and K. Van't Riet. 1991. Modeling of bacterial growth as a function of temperature. Appl. Environ. Microbiol. 57:1094-1101.

Zwietering, M. H., J. C. De Wit, H. G. A. M. Cuppers, and K. Van't Riet. 1994. Modeling of bacterial growth with shifts in temperature. Appl. Environ. Microbiol. 60:204-213.

Zwietering, M. H., I. Jongenburger, F. M. Rombouts, and K. Van't Riet. 1990. Modeling of the bacterial growth curve. Appl. Environ. Microbiol. 56:1875-1881. 